DOI https://doi.org/10.32782/2305-9389/2020.23.09

УДК 9-05(292.451/.454)(=16)“1807/1872”

Трубчанінов Сергій, кандидат історичних наук, дочент кафедри історії України Кам'янець-Подільського національного університету імені Івана Огієнка

\title{
УКРАЇНСЬКІ ЗЕМЛІ В ІСТОРИКО-ГЕОГРАФІЧНІЙ ВІЗІЇ ВІНЦЕНТІЯ ПОЛЯ
}

У статті розповідається про визначного польського поета-романтика Вінцентія Поля (1807-1872), якого навіть називали «четвертим поетом-пророком». Він був також відомий як географ, етнограф $і$ політичний діяч. Дослідники історії польської географічної науки особливо наголошують, шьо кафедра географії в Кракові, де праиював В. Поль, стала другою в Свропі та світі після кафедри Карла Ріттера в Берліні. Саме йому належить запровадження терміна «Креси» в розумінні колишніх східних земель Речі Посполитої.

Уродженеиь Любліна, виходець з ополяченої німецько-франиузької родини, значну частину свого життя він провів у Галичині. Тут він зростав, навчався, робив свої перші спроби в поезії та науиі. Так, на межі 1830-1840-х років він об '̈̈хав Карпати - від Буковини до Сілезії, вивчав фізичну географію та етнографію краю. У 1842 р. в кількох числах надзвичайного додатку до «Львівської газети» В. Поль опублікував свою розвідку щңодо географії Галичини. Він готував грунтовну пращю з географії та етнографї Польщі, проте більшість матеріалів згоріли під час селянського заворушення на початку 1846 р.

Наприкінці 1849 р. завдяки підтримизі австрійського міністра культів і освіти В. Поль очолив новоутворену кафедру загальної, фізичної і порівняльної географії Краківського університету. Більшість із опублікованих географічних праць В. Поля - тексти лекцій, які він читав на початку 1850-х рр. у Кракові. В. Поль викладав географію Австрійської монархії, етнографію, географію Святої землі та низку інших навчальних курсів. Серед географічних дисииплін важливе значення вчений відводив історичній географії. Незважаючи на те, щзо з 1 січня 1853 р. В. Поль перестав бути професором, а його кафедра була ліквідована, він не полишав зацікавленості географічними студіями і в подальші роки.

У n'яти листах до Ф. Духіньського (1867) В. Поль найбільш повно виклав власну історико-географічну візію польських земель, якими він вважав усі території, щьо колись входили до складу Речі Посполитої. На його думку, географічне розташування є природним фундаментом для історії. В. Поль вважав, щзо східний кордон Європи йшов не по Уралу та Кавказу, а відразу за басейнами річок Двіна та Дніпро.

Ключові слова: Вінцентій Поль, історична географія, українські землі, Карпатські гори, Річ Посполита.

Trubchaninov Serhii. Ukrainian Lands in Wincenty Pol's conception of historical geography

A prominent Polish romantic poet Wincenty Pol (1807-1872) was called "the Fourth prophetic poet". Also he was well known as geographer, ethnographer and politician. Researchers of history of Polish geographical science especially emphasize that second cathedra of geography in Europe and the world after cathedra of Karl Ritter in Berlin has been hold by Wincenty Pol in Krakow. He was an author of term "Kresy" in the meaning of former eastern lands of Commonwealth of Poland.

Being a native of Lublin from assimilated German-French family he spent a big part of his life in Halychyna. That was the place where he rose, studied and made his first steps in poetry and science. In 1830-1840-s he had a trip around Carpathians and studied physical geography and ethnography of the region. In 1842 he published his research on geography of Halychyna in additions to "Gazeta Lwiwska". He prepared a grounded work about geography and ethnography of Poland but a lot of materials was burned away when peasant's riots happened at the beginning of 1846.

In the end of 1849 Wincenty Pol hold the newly-formed cathedra of general, physical and comparative geography in University of Krakow. A majority of his published works were texts of his lectures at the beginning of 1850-s. Scientist gave an important place for historical geography among other geographical disciplines. Wincenty Pol taught geography of Austrian monarchy, ethnography, geography of Holy Land and some other courses. Despite of his dismissal he was still interested in geographical studies.

In five letters to Franciszek Duchiński (1867) Wincenty Pol suggested his own conception of historical geography of Poland and former lands of Polish-Lithuanian Commonwealth. In his opinion, geographical location was a natural basement of history. Wincenty Pol considered that eastern border of Europe was after drainage basins of rivers Dvina and Dnipro.

Key words: Wincenty Pol, historical geography, Ukrainian Lands, Carpathian Mountains, Polish-Lithuanian Commonwealth.

Видатного польського поета-романтика Вінцентія Поля (1807-1872) часто називають «четвертим поетом-пророком». Але важливо наголосити, що він також відомий як визначний географ, етнограф і політичний діяч. У польській історіографії особливо підкреслюється, що кафедра географії в Кракові, яку В. Поль очолював у 1849-1852 рр., стала другою в Свропі та світі після кафедри К. Ріттера в Берліні 
[1, с. 26]. У багатьох десятках праць польських дослідників висвітлюється його діяльність у царині географії та природознавства. Особливо плідним періодом у цьому плані є початок XXI ст. За нашими підрахунками, лише в трьох тематичних збірках наукових праць, які вийшли у 2006, 2014, 2015 рр., опубліковано 57 статей сучасних дослідників, кілька робіт В. Поля та праць 1920-х рр. [2-4].

Як відомо, В. Поль першим вжив термін «Креси» в розумінні східних територій колишньої Речі Посполитої. Саме ця обставина привертає найбільшу увагу українських дослідників під час вивчення його діяльності [5]. Проте інші сторінки інтелектуальної біографії В. Поля не знайшли належного висвітлення в українській історіографії. Частково цього питання ми торкнулися у своєму монографічному дослідженні [6].

Метою статті $\epsilon$ показ етапів становлення В. Поля як вченого-географа, аналіз його науково-педагогічної діяльності, характеристика історико-географічних поглядів, висвітлення місця українських земель у його творчості.

Уродженець Любліна, виходець з ополяченої німецько-французької родини, значну частину свого життя В. Поль провів у Галичині. Тут він зростав, навчався, робив свої перші спроби в поезії та науці. Під час навчання у Львові, Тернополі й Вільно у 1819-1830рр. він здійснив перші подорожі (околиці Львова, Поділля, Волинь, Полісся, Литва), які вплинули на його зацікавленість дослідженнями з географії, природознавства та етнографії [7, с. 257]. Як співець Листопадової революції, В. Поль здобув величезну популярність після іiї поразки, оприлюднивши в 1835 р. збірку «Пісні Януша» [8, s. 130-131].

Як і багато хто з поетів, він неодноразово звертався до описів природи. Але в цьому й проявлявся його хист науковця, адже він намагався якнайглибше пізнати, зрозуміти і описати природу та іiі явища [9, s. 29]. У 1835 р. під час перебування в гостях у маєтку Тадеуша Скжинського в Загужанах коло Горлиці В. Поль написав поему, де описав подорож давніми землями Речі Посполитої. Вперше «Пісня про наш край» без вказівки на авторство була надрукована в 1843 р. у Познані. Це один із найвідоміших творів поета, який часто називають «поетичною географією Польщі», «поетичною етнографією» чи навіть «підручником патріотизму» [10, s. 60-61].

Поет майстерно описує польські землі, якими він вважав всі території, що раніше входили до Речі Посполитої. Оповідач розповідає, як виїхавши з Литви і проїхавши болота і пущі, Пінською дорогою він потрапляє на Русь - «пашнисту, рівну, суху, нелісисту». Вона здається мандрівникові справжнім раєм! Перша частина Русі, яку він побачив, - це Волинь, якщо ж поїхати ліворуч - буде квітуча, чорноземна Україна, якщо ж прямо аж до Дністра - Поділля, а вздовж Дністра - Побережжя [11, s. 30-32].

В. Поль із захопленням розказує про особливості кожного з регіонів. Так, на Волині його вразили ставки, на яких збиралися величезні зграї диких птахів. Спостерігаючи їхню поведінку, слухаючи пташине гелготання, поет порівнює поведінку птахів із сеймовими баталіями, залицяннями та бенкетами. До багатств Волині він зараховує велику кількість риби, збіжжя, свинини, великої рогатої худоби, коней, диких тварин, конопель, бджіл і меду, підкреслюючи також велику кількість мешканців краю [11, с. 33-34]. Оповідаючи про чудові українські краєвиди, затишні села та мальовничі міста, В. Поль із захопленням вигукує: «Нам жить тільки в Україні!», або ж: «Об’їзд цілий світ і перепливи море, немає кращого краю за Поділля!» [11, s. 45, 50].

Проте, милуючись українською природою, оповідач бачить деспотизм панів та їхніх слуг і тяжку долю простого люду. Він також з обуренням говорить про панство, яке перейшло на російський бік: «Гірший, ніж пан на Волині, є пів-панок на Поділлі!». Поет пише, що шляхта, яка утворила Тарговицьку конфедерацію, завинила перед Богом, вірою та минулим [11, s. 34-42, 54-55].

Історики польської географії та дослідники творчості В. Поля наголошують, що на межі 1830-1840-х років він особливо грунтовно вивчав фізичну географію. Разом із ботаніком Гіацинтом Конти Лобажевським В. Поль об’їхав Карпати - від Буковини до Сілезії. Особлива увага була приділена вивченню верхів'їв Дністра, Прута, Вісли та Одера. У 1843 р. В. Поль та Г. Лобажевський навіть виявили одне із джерел, з яких витікає Вісла (через століття біля витоку Чорної Віселки було встановлено пам'ятну плиту на честь цього відкриття) [12, s. 369-372; 13, s. 124].

Самопідготовці В. Поля в галузі географії допомагали також наукові дискусії з філософом Юзефом Кремером та геологом Людвиком Зейшнером, які свого часу слухали в Берліні лекції К. Ріттера. Також В. Поль вивчав твори О. Гумбольдта, К. Ріттера та іншу новітню літературу в галузі географічних наук $[10$, s. 60]. Молодий польський учений листувався з О. Гумбольдтом і навіть зустрічався 3 ним. Він також спілкувався на наукові теми з відомим чеським натуралістом Яном Пуркине [14, s. 312-316].

У кількох числах надзвичайного додатку до «Львівської газети» в 1842 р. В. Поль опублікував свою розвідку щодо географії Галичини «Погляд на північні схили Карпат (під кутом зору природи)». Редакція часопису в передмові до цієї праці зазначала, що автор підготував нарис за ії ініціативою спеціально 
для «Львівської газети», у той же час він планує видати в недалекому майбутньому «Опис Північного Сходу Європи». У першій статті В. Поль охарактеризував гідрографічну мережу регіону (басейни Вісли, Дністра та Пруту, а також проекти будівництва каналів) [15], у наступній - ландшафт краю [16].

На жаль, грунтовна праця В. Поля з географії та етнографії Польщі, підготовлена до друку разом із картографічним матеріалом, яка містила опис близько 4 тис. річок, згоріла під селянського заворушення на початку 1846 p. [17, s. 4-8]. Тоді ж було знищено більшу частину циклу поезій «Свята катеринка», в якому В. Поль розмірковував над історичною долею своєї батьківщини. Так, в історикогеографічній «Картині ІІІ» показано його бачення слов'янської землі, згадуються річки, що впадають у Чорне та Балтійське моря, а також люди, які використовують їх (литвини, русини й поляки). Розповідаючи про переломні моменти польської історії, В. Поль вказував, що були періоди, коли виникали можливості для піднесення нації, але занадто часто ці можливості втрачалися через неправильні дії поляків. Серед позитивних героїв, зображених поетом, бачимо гетьмана Я. Тарновського, літописця Я. Длугоша, єзуїта П. Скаргу, астронома М. Коперника, короля Яна Собеського та ін., серед негативних - королеву Бону [18].

Революційні події 1848 р., слов'янський конгрес у Празі викликають у В. Поля інтерес до давньої історії слов'ян. У поетичній формі він доводить, що племінна назва слов'ян походить від божественного слова, тобто слов'яни є носіями «Слова Божого» [19, s. 91-92].

Згодом через поліцейський тиск щодо активних учасників подій «Весни народів» у Галичині В. Поль був змушений залишити Львів. Після короткого перебування в Марієнбаді та Празі восени 1849 р. він приїхав до Відня, де зустрівся із нещодавно призначеним міністром освіти графом Л. фон Тун-Хохенштайном. Останній у 1846-1848 рр. обіймав посаду державного радника у Галичині, був знайомий із В. Полем та добре знав про його наукові амбіції. Саме тому міністр і запропонував йому очолити кафедру польської літератури у Краківському університеті. Проте В. Поль не прийняв цієї пропозиції - за однією з гіпотез він сказав, що йому нічого додати до лекцій А. Міцкевича про слов'янську літературу. У той же час він виступив з ініціативою створення кафедри загальної, фізичної і порівняльної географії. 8 листопада 1849 р. В. Поль отримав указ цісаря про призначення його екстраординарним професором із річною платнею 1,2 тис. ринських золотих [17, s. 109-110, 112-113]. Кафедра географії у столичному Віденському університеті з'явилася лише весною 1851 р., ії очолив відомий дослідник Альп Фрідріх Сімоні [20, s. 10-13].

У Краків В. Поль прибув 18 листопада 1849 р. та відразу ж розпочав енергійну підготовчу роботу отримавши 500 ринських золотих дотацій від керівництва вишу, придбав для бібліотеки кілька десятків наукових праць та часописів із географії; звернувся з листами до багатьох колекціонерів і меценатів із проханням допомогти із поповненням збірок університету. Коли 10 січня 1850 р. послухати лекцію В. Поля зібралося чимало бажаючих, він добився від керівництва встановлення плати за відвідування лекцій сторонніми особами, а отримані за це кошти були спрямовані на харчування бідних студентів [21, s. 37-38].

Приступаючи до викладання курсу загальної, фізичної та порівняльної географії, В. Поль виголосив лекцію, в якій охарактеризував своє бачення географії як академічної дисципліни. Вчений наголошував, що географічна наука $є$ дуже давньою та спершу розвивалася в тісному зв'язку з історією та політикою, важливе значення для її становлення мали праці Аристотеля. У XVIII ст., коли географічні знання сягнули високого рівня розвитку, з'явилася так звана «чиста географія», відірвана від історії та політики $[22$, s. $119,121,123]$. В. Поль вказував на тісний зв'язок географії з мінералогією, метеорологією, ботанікою, зоологією та ін. науками, внаслідок чого виникли такі підрозділи географії: геологія, кліматологія, географія рослин, географія тварин, етнографія [22, s. 124-132]. Важливе значення вчений відводив історичній географії, яку він вважав частиною загальної географії, а не окремою наукою [22, s. $133-135]$.

Протягом 1849/1850, 1850/1851 та 1851/1852 н. р. В. Поль викладав курс географії Австрійської монархії, проте розмножені літографськими засобами тексти лекцій, супровідні їм карти, а також рукописи стосовно регіонів Альп, Судетів, Подунав'я та Карпатів були знищені під час великої пожежі 18 липня 1850 p. [23, s. 2]. У зв'язку з цим на початку 1851 р. учений вирішив оприлюднити свій курс «Погляд на північні схили Карпат», в якому охарактеризовано ландшафт регіону [23, s. 3-29], його гідрографічну мережу [23, s. 31-49], поділ природи краю на три світи (світ гір, світ холодних, вологих північних рівнин, степовий світ) [23, s. 51-80], карпатські перевали та шляхи біля підніжжя гір [23, s. 81-94], а також етнографічні групи [23, s. 95-116].

У 1851/1852 н. р. В. Поль читав, зокрема, курс етнографії. Свідчення про етнографію Галичини учений черпав із різних джерел, до окремих з яких він ставився досить скептично. Тому, розповідаючи про 
етнографічні групи т. зв. «куртаків» чи «чухоньців», які мешкали в Низьких Бескидах, автор вказує, що хоча їх і називають «лемками», - від слова Lem, яке вони вживають, немає підстав для творення їхньої особливої історії. В. Поль, кепкуючи, зазначив, що так само можна було б взятися за історію для народу «немків» чи «лежків», адже в трьох селах понад Ославою в одному люди кажуть «лем», в іншому «нем», в третьому - «леж» [23, s. 111].

У лютому 1851 р. вийшов друком ще один курс В. Поля «Північний схід Європи з погляду природи». У передмові до книги зазначалося, що курс, призначений для студентів та усіх бажаючих, читався в 1850 р. та був старанно законспектований одним із слухачів. У двох частинах йшлося про природу величезної території (від Карпатських гір до Балтійського моря), з акцентом на гідрографічну мережу цього субрегіону Свропи [24]. Третю частину цього курсу становили «Картини із життя та природи». Ці «картини» були написані автором пізніше та 3 різного приводу. Так, «Пам'ятка про Дністер» з'явилася на межі 1850-1860-х років, у зв'язку з планами організації пароплавства на Дністрі. У цьому творі В. Поль називає головні історичні події XV-XVII ст., інформує про картографічні роботи у XVII-XVIII ст., про спроби налагодження судноплавства у XIX ст. (у т. ч. про спорудження прибережних дамб у 1845 р.), про значення Одеси в торгівлі збіжжям [25, s. 251-258]. Автор публікує меморіал Львівського господарчого товариства про важливість Дністра для Галичини як шляху водного та торгівельного та ін. У цьому документі перелічувалися десятки різних товарів, які планувалося перевозити Дністром. Зокрема, вказувалося, що товари, що надходили до Австрії з Азії морським шляхом навколо Африки до порту Трієст або ж через Англію чи Гамбург, у разі надходження через чорноморські порти будуть значно дешевшими [25, s. 265-266].

У Краківському університеті В. Поль також викладав географію Палестини і Сирії на теологічному відділі. Доопрацьований курс «Географії Святої землі» пізніше було видано у Львові (1862) [26].

3 весни 1850 р. В. Поль організовував для студентів екскурсії за межі Кракова - до маленьких містечок, до Нєполоміцької пущі, в гори. У великій вилазці в Татри і Пеніни в липні-серпні 1852 р. брало участь близько 100 осіб. Під час цієї екскурсії молодь встановила в гірській долині дерев'яний хрест iз написом «І нічого над Богом» та заспівала кілька патріотичних пісень. Дізнавшись про це, професор кафедри загальної історії А. Валевський, який неприязно ставився до В. Поля, написав донесення міністру поліції, в якому трактував екскурсійну діяльність ученого-географа як підготовку до революції. Вже 30 вересня 1852 р. цісар підписав розпорядження про відставку чотирьох професорів Краківського університету, внаслідок чого з 1 січня 1853 р. В. Поль перестав бути професором, а його кафедра була ліквідована [27, s. 63-65].

Упродовж 1840-1852 pр. В. Поль працював над поемою «Мохорт», яка побачила світ на початку 1855 р. Публікація твору стала справжньою сенсацією в польському суспільстві. У поемі, яку називали «молитвою польських душ», новий світоглядний зміст одержав термін «kresy», зафіксований у вжитку ще в XV ст. Дослідники підкреслюють, що В. Поль відіграв чи не головну роль у змалюванні ідилічної України, яка спершу існувала тільки в уяві «української школи» і ії прихильників та виросла «до рангу центральної сцени польської національної історії» [5, с. 174, 176].

В. Поль продовжував цікавитися географією і в наступні роки, вже не обіймаючи посади професора. У п’яти листах до Ф. Духіньського (1867) учений і поет виклав власну історико-географічну візію Польщі. Зокрема, він наголошував, що виходить із того переконання, що географічне розташування $\epsilon$ природним фундаментом для історії [28, s. 4]. В. Поль закликав боротися з німецькими географами їхньою ж зброєю, доводячи хибність їхніх теорій. Зокрема, він вважав, що Німецька низовина відокремлена від польських рівнин; в історичного простору Польщі власна ідея, що відображена в окремішності Польської землі; східний кордон Свропи проходив не гірськими хребтами Уралу та Кавказу, а відразу за басейнами річок (Зах.) Двіни та Дніпра; басейн Волги належить вже до Центральної Азії [28, s. 7-8].

Як відомо, представники «української школи» відсували на задній план «Україну гайдамаків і козаків». Для них Україна - шляхетська, рицарська, бравурна, сповнена «родової фантазії», що кохається в конях, ярмарках, торговищах, безкомпромісна в любові і помсті; іiі отамани набувають шляхетства, шляхтич стає рицарем-християнином, простий народ ледь чи не з радістю піддається полонізації, а «благородний козак-рицар» перетворюється на «кращого друга поляків» [5, с. 176]. Саме тому В. Поль вважав запорізьких козаків деструктивною силою в історії Польщі, оскільки, на його думку, вони «жили тільки грабунком сусідніх країн» [28, s. 19]. Стосовно ж Москви він особливо наголошував на азійському характері її правління, звичаях тощо [28, s. 21].

На думку В. Поля, межею між Європою і Азією були вододіли, що відокремлюють басейни Дніпра i (Зах.) Двіни від басейнів Волги й Дону [28, s. 26]. Важливим географічним об'єктом учений називав Карпатські гори, які з півдня обмежували рівнини Польщі й Русі. На північних схилах мешкали різні 
етнографічні групи поляків і русинів, які по-різному називали гірські хребти та інші форми рельєфу [28, s. 30-33]. В. Поль виділив окремі історико-географічні регіони, вказав на їхні межі, висловив міркування щодо походження назви. Так, щодо Волині він зазначив, що це родюча країна, наполовину вкрита лісом, наполовину зайнята орними полями і луками. Її назву В. Поль пов'язував із народним уявленням, що цей край найкраще придатний для вирощування великої рогатої худоби [28, s. 34$]$.

Польський географ вважав, що на «історичних польських землях» важливу роль мали наступні ріки: Варта $з$ притокою Нотець у басейні Одри, Буг із Нарвою в басейні Вісли, Вілія в басейні Німану, Прип'ять і Березина в басейні Дніпра, Стрий, а також Сан із Віслоком у передгір'ях Карпат [28, s. 47]. Учений вказував, що через рівнину між Одером і Дніпром проходила свого роду «стратегічна лінія» від Костшина (місце впадіння Варти в Одер) до Чорнобиля (місце впадіння Прип’яті в Дніпро). Спираючись на неї, «національна сила Польщі» давала відсіч натискам з усіх боків. Так, озерна Великопольща, Мазовше і Пінщина захищали Сілезію, Малопольщу, Поділля, Волинь і Україну з боку Помор'я, Пруссії та Верхньої Литви [28, s. 49].

В. Поль підкреслював, що пороги на Дніпрі нагадують про діяльність Запорозької Січі, пороги на Дністрі - про боротьбу з волохами, татарами і турками, пороги на (Пд.) Бугові - про Чорний і Кучманський шляхи, якими відбувалося нашестя зі сходу [28, s. 50]. На думку польського ученого, джерело козацтва було не руське, а азійське, а також гайдамацьке. Спустошену ж Україну залюднювали вихідці з Поділля, Волині та Овруччини. Іншим гніздом, з якого вирушала «рільнича людність» на Русь, Литву і всю Польщу, було Мазовше [28, s. 51].

Польський географ допускав, що над берегами Одера, Вісли, Дністра й Дніпра в давнину існували численні поселення полян, відомих під різними назвами. Оскільки південно-східна частина цього обшару не була сприятлива для рільництва через брак водних ресурсів, мешканці Поділля споруджували численні ставки на допливах Дністра, починаючи від річки Верещиці. У басейні Пд. Бугу ставки будувалися від верхів'я Бугу до впадіння в нього Синюхи. Цілі ланцюжки ставків на Волині були на річках Ікві, Стирові, Горині й Случі, а на Україні (тобто в межах колишнього Київського воєводства. C. T.) - на Тясмині, Ірпені, Тетереві й Росі. В. Поль підкреслював, що такої кількості штучних водосховищ в Європі більше ніде не було. Численні ставки, на його думку, змінили на краще рільництво краю. Саме тому вчений із болем звертав увагу на занепад ставкового господарства, який він міг спостерігати [28, s. 53-58]. Українська степова природа зумовила також появу численних хуторів, майданів, гут та ін. на південному сході [28, s. 59].

Поріччя Вісли, на думку В. Поля, стало осердям польської історії, оскільки вона була «панівною річкою» на Балтиці, у той час як такою річкою в Чорноморському басейні був Дунай. Він підкреслював, що напрямок течії Дніпра нагадує Рону. Обидві річки є свого роду природним рубежем, за Роною Франція, за Дніпром - Азія [28, s. 60-61]. Якщо для історії Західної Свропи важливе значення як комунікації мали річки, то для українських територій такими були степові (татарські) шляхи. Але цими шляхами приходили й нападники, від яких мусила оборонятися й ховатися місцева людність [28, s. 62-82].

У доповідях на засіданнях Краківського наукового товариства взимку 1868-1869 рр. В. Поль оприлюднив свій п'ятий лист Ф. Духінському, присвячений діалектам польської мови [28, s. 82-136]. I знову він наголосив на великому впливі річкової мережі на розселення і розвиток польського народу [28, s. 92-93]. «Плем'я полян мало бути дуже сильним і потужним, - писав В. Поль, - коли вихідці з-над Вісли могли залюднити цілий пізніший простір польської Речі Посполитої» [28, s. 120]. На його думку, поляни вийшли 3 низин у середній течії Одера й Вісли та вирушили в різних напрямах. Зокрема, рух відбувався вздовж (Зах.) Бугу вгору за течією, аж до його витоків. 3 Волинської височини поляни розійшлися в різні боки, заселивши Волинь, Поділля аж до Дністра, лісисте Полісся Волинське й Київське (племена древлян), околиці Києва (поляни дніпровські), верхів'я Дніпра (кривичі, дреговичі й полочани) [28, s. 121-122].

В. Поль виділяє окремий «опольський» діалект польської мови. Окреслений ним регіон «Ополє» на півночі сягав до Волинського й Київського Полісся, на заході - до вододілу Сяну й Верхнього Дністра, на півдні - до Пруту, на сході - до Дніпра [28, s. 127]. На його думку, територія України (тобто Київщина - C. T.), яка часто спустошувалася внаслідок татарських нападів, знову й знову заселялася вихідцями з Овруччини (нащадками древлян), у той час як Побережжя, теж відкрите нападникам, заселялося вихідцями із Волині [28, s. 131]. В. Поль вважав, що «відрубність Південного Ополя», яка знайшла відображення в польській літературі, була на шкоду національній справі, оскільки, на його думку, це спростовувалося походженням, мовою, звичаями та історією населення краю [28, s. 132].

Отже, визначний польський поет, «перший географ» В. Поль поділяв ідеї географічного детермінізму. Найбільш повно свою історико-географічну візію він виклав у працях, що з'явилися вже у зрілому віці. Провідну роль в історичному розвитку народів В. Поль відводив їхньому географічному розташуванню. Межі історичної Польщі, на його думку, простягалися від Одера на заході до Дніпра 
на сході. Він вважав, що спершу ця територія була заселена різними польськими племенами, батьківщиною яких був край у середній течії Вісли. На його думку, з утворенням Речі Посполитої до їі складу цілком легітимно увійшли давні польські землі на сході. На його ментальній мапі Русь - східна частина колишньої Речі Посполитої, Україна - це лише територія колишнього Київського воєводства. Він заперечував існування окремого українського народу, а росіян вважав ослов'яненими туранцями.

\section{Література:}

1. Jackowski A., Sołjan I. Wincenty Pol jako geograf. Wincenty Pol (1807-1872). W stużbie nauki i narodu / pod red. Krystyny Grodzińskiej i Adama Kotarby. Kraków : Polska Akademia Umiejętności, 2010. S. 25-47.

2. Wincenty Pol jako geograf i krajoznawca / pod red. Antoniego Jackowskiego i Izabeli Sołjan. Kraków : Uniwersytet Jagielloński, Instytut Geografii i Gospodarki Przestrzennej, 2006. 240 s.

3. Świat Wincentego Pola : Język i natura. Natura i naturaliści / pod red. Tadeusza Piersiaka. Lublin : Muzeum Lubelskie w Lublinie, 2014. $144 \mathrm{~s}$.

4. Obrazy natury i kultura. Studia o Wincentym Polu / pod red. Małgorzaty Łoboz. Wrocław : Agencja Wydawnicza a Linea, 2015. $688 \mathrm{~s}$.

5. Шама О. Поема польського поета Вікентія Пола «Мохорт» і ії значення у формуванні поняття «Креси». Наукові записки Тернопільського начіонального педагогічного університету імені Володимира Гнатюка. Сер. Історія. 2014. Вип. 1. Ч. 2. С. 173-180.

6. Трубчанінов С.В. Конструювання національного простору: історико-географічні уявлення в українській науковій $\mathrm{i}$ суспільно-політичній думці 1830-1930-х рр. : монографія. Кам’янець-Подільський : Оіюм, 2019. 480 с.

7. Harasimiuk K., Harasimiuk M. Pionierskie badania krajoznawcze Stanisława Staszica i Wincentego Pola w Karpatach. Пpoблеми геоморфології і палеогеографії Українських Карпат і прилеглих територій : збірник наук. пр. Львів : Видавничий центр ЛНУ імені Івана Франка, 2006. С. 251-265.

8. Bondos K. Obcy wśród swoich - romantyczna biografia Wincentego Pola. Spoleczeństwo. Edukacja. Język / Państwowa Wyższa Szkoła Zawodowa w Płocku. 2018. Tom 7. S. 129-145.

9. Lyszczyna J. Wincenty Pol i romantyczne odkrywanie natury. Świat Wincentego Pola : Język i natura. Natura i naturaliści. S. $25-30$.

10. Jackowski A., Sołjan I. Wincenty Pol «ojciec» nowożytnej geografii polskiej. Wincenty Pol jako geograf i krajoznawca. S. 51-96.

11. Pol W. Pieśń o ziemi naszej / wyd. 2-e. Poznań : Nakładem księgarni J. K. Żupańskiego, 1852. 155 s.

12. Mann M. Wincenty Pol : studjum biograficzno-krytyczne. T. 1. Kraków : G. Gebethner i Spółka, 1904. [6], 402 s., [1] k. tabl.

13. Pociask-Karteczka J. Hydrografia w pracach Wincentego Pola. Wincenty Pol jako geograf i krajoznawca. S. 115-132.

14. Zielnica K. Alexander von Humboldt und die polnischen Naturforscher in Galizien. Wissenschaftskolleg : Jahrbuch 1981/82 / hg. Peter Wapnewski. Berlin : Quadriga-Verlag, 1983. S. 303-329.

15. Pol W. Rzut oka na Północne stoki Karpat (Pod względem Przyrodzenia). Artykuł I. Wodna sieć kraju. Dodatek nadzwyczajny do Gazety Lwowskiéj / red. J. N. Kamiński. Lwów : Nakładem Spadkobierców F. Krattera, 1842. 24 marca. S. 1-4; 10 maja. S. $1-2 ; 14$ czerwca. S. 1-4.

16. Pol W. Rzut oka na Północne stoki Karpat (Pod względem Przyrodzenia). Artykuł II. Kształt I powierzchnia kraju. Dodatek nadzwyczajny do Gazety Lwowskiéj. 1842. 28 czerwca. S. 1-4.

17. Mann M. Wincenty Pol : studjum biograficzno-krytyczne. T. 2. Kraków : G. Gebethner i Spółka, 1906. [4], 464 s., [2] k. tabl.

18. Bondos K. Wincenty Pol na krańcach świata literackiego. Romantycy na krańcach Świata. Podróże egzotyczne i peregrynacje wewnętrzne / pod red. Ewy Modzelewskiej i Pawła Sobola. Kraków : Księgarnia Akademicka, 2015. S. 163-176.

19. Michalski M. Dawni Słowianie w tradycji polskiej pierwszej połowy XIX wieku: W poszukiwaniu tożsamości wspólnotowej. Poznań : Wydawnictwo Poznańskie, 2013. 290 s.

20. Penck A. Friedrich Simony : Leben und Wirken eines Alpenforschers. Ein Beitrag zur Geschichte der Geographie in Österreich. Wien : Hölzel, 1898. 113, XXII s. (Arbeiten des Geographischen Institutes der K. K. Universität Wien; Heft 6).

21. Ziejka F. Krakowskie lata Wincentego Pola. Wincenty Pol jako geografi krajoznawca. S. 31-49.

22. Pol W. Rzut oka na umiejętność geografii ze stanowiska uniwersyteckiego wykładu. Dzieła Wincentego Pola wierszem i proza / 1-e wyd. zupełne, przejrzane i uporządkowane przez samego autora. T. VI = Serya druga : Dzieła prozą. T. III. Lwów : Nakładem F. H. Richtera, 1877. S. 117-135.

23. Pol W. Rzut oka na Północne stoki Karpat (Prelekcye). Dzieła Wincentego Pola wierszem i proza. T. VI = Serya druga : Dzieła prozą. T. III. Lwów : Nakładem F. H. Richtera, 1877. S. 1-116.

24. Pol W. Północny wschód Europy pod wzlędem natury (Cz. I, II). Dzieła Wincentego Pola wierszem i prozą. T. II = Serya druga : Dzieła prozą. T. I. Lwów : Nakładem F. H. Richtera, 1875. $454 \mathrm{s.}$

25. Pol W. Pamiętnik o Dniestrze. Dzieła Wincentego Pola wierszem i proza. T. IV = Serya druga : Dzieła prozą. T. II. Lwów : Nakładem F. H. Richtera, 1876. S. 251-317.

26. Pol W. Geografja Ziemi Świętéj w dwóch księgach. Dzieła Wincentego Pola wierszem i proza. T. VI = Serya druga : Dzieła prozą. T. III. Lwów : Nakładem F. H. Richtera, 1877. S. 231-387, 2 tabl.

27. Barycz H. Wincenty Pol jako profesor geografii na Uniwersytecie Jagiellońskim. Prace komisji historii medycyny i nauk matematyczno-przyrodniczych / Polska Akademia Umiejętności. Kraków, 1949. № 3. S. 43-128.

28. Pol W. Historyczny obszar Polski (Pięć listów do Duchińskiego). Dzieła Wincentego Pola wierszem i prozą. T. X = Serya druga : Dzieła prozą. T. V. Lwów : Nakładem F. H. Richtera, 1878. S. 1-136. 